\title{
Identifying Neolithic animal management practices in the Adriatic using stable isotopes
}

\author{
Emily Zavodny"1, Sarah B. McClure', Brendan J. Culleton' ${ }^{1}$, Emil Podrug ${ }^{2}$ \\ and Douglas J. Kennett ${ }^{1}$ \\ 1 Department of Anthropology, The Pennsylvania State University, USA \\ ekz5008@psu.edu \\ 2 Šibenik City Museum, Šibenik, HR
}

\begin{abstract}
We synthesise reported stable isotope values for domesticates and wild herbivores from sites spanning the Neolithic in coastal Croatia, Slovenia, and Italy (6000-3500 calBC). Carbon and nitrogen stable isotope values are analyzed as proxies of diet and environment, with differences between species possibly indicating anthropogenic influence. Results are used to characterise diets and address questions of the origin and development of husbandry strategies, especially transhumance, in early farming communities. Changes in pig carbon and nitrogen isotope values through time suggest alterations in practices, whereas values remain relatively constant for cattle and ovicaprids during most of the Neolithic, despite assumptions of seasonal mobility.
\end{abstract}

IZVLEČEK - V prispevku sintetiziramo vrednosti stabilnih izotopov domačih in divjih (rastlinojedih) živali iz neolitskih obmorskih najdišč na Hrvaškem, $v$ Sloveniji in v Italiji (v časovnem obdobju od 6000 do 3500 calBC). Vrednosti stabilnih izotopov ogliika in dušika smo analizirali kot približke za podatke o prehrani in okolju; razlike v teh vrednostih med vrstami živali morda kažejo na antropogene vplive. S pomočjo rezultatov teh analiz smo lahko prepoznali značilnosti prehrane v zgodnje poljedelskih skupnostih na teh območjih in odgovorili na vprašanja o izvoru in razvoju živinorejskih strategij, predvsem transhumance. Spremembe v vrednostih ogljika in dušika pri prašičih v različnih časovnih obdobjih kažejo na spremembe v postopkih prašičereje, medtem ko so te vrednosti za govedo in ovce/koze ostale relativno nespremenjene skozi celoten neolitik, kljub temu da se za te živali predvideva sezonska mobilnost.

KEY WORDS - Neolithic; Adriatic; transhumance; domestication; stable isotopes

\section{Introduction}

New stable isotope and lipid residue studies have begun to map and characterise the spread of livestock management practices throughout the Adriatic and Balkans during the Neolithic (c. 6000-3500 calBC; Budja et al. 2013; Evershed et al. 2008; Lelli et al. 2012; Lightfoot et al. 2011; Šoberl et al. 2008; Zavodny et al. 2014). Scientific advances have also allowed for a more fine-grained view of how Neolithic lifeways varied by site and region, with emphasis placed on secondary product exploitation or the seasonal movement of animals. However, some inte- gral aspects of livestock management (e.g., foddering and grazing) are less visible through traditional archaeological methods. Stable isotope studies offer a systematic approach to mapping these activities both temporally and geographically, and have been applied successfully in a variety of contexts (e.g., Bocherens et al. 2000; 2001; Makarewicz, Tuross 2006; Pearson et al. 2007).

Stable carbon and nitrogen isotope analyses are especially important for inferring changes in diet and

* corresponding author 
environment indicative of anthropogenic influence in the absence of a complete archaeological record. Here we synthesise published stable carbon and nitrogen isotope data from open-air settlements and cave sites in the Adriatic region spanning the Early to Late Neolithic (see Fig. 1; Lelli et al. 2012; Lightfoot et al. 2011; Ogrinc, Budja 2005; Zavodny et al. 2014). Comparison of these data can help to identify differences in animal diet between species and through time that may be linked to changes in animal management and exploitation, providing a framework for interpreting management strategies and issues of domestication on a regional scale.

\section{Background}

Stable isotope studies of domesticated faunal remains have recently advanced our understanding of the origin and spread of agriculture in the Mediterranean world (Lelli et al. 2012; Lightfoot et al. 2011). Ongoing archaeological studies focus on the introduction, adoption,

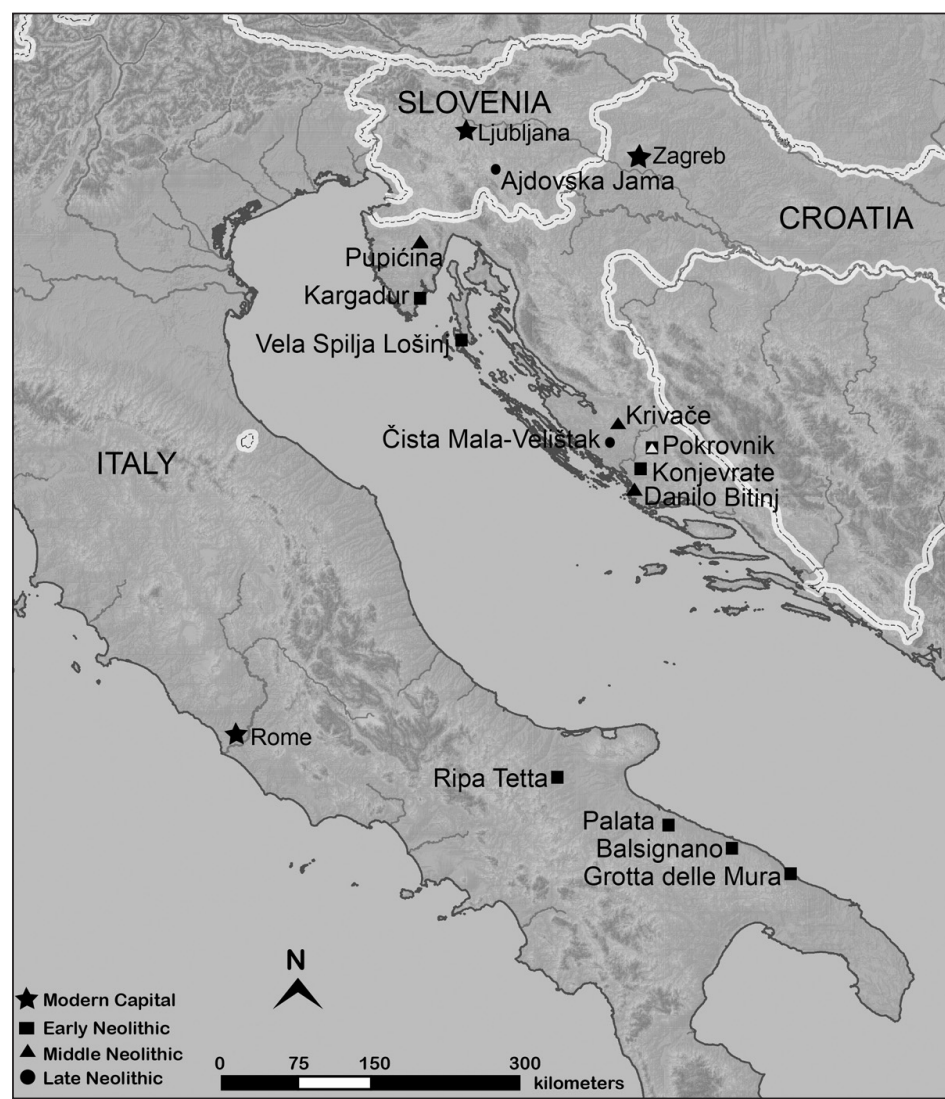

Fig. 1. Map of Neolithic sites mentioned in the text. and adaptation of domesticates by early farming communities and hunter-gatherer groups (Bass 2008; Lelli et al. 2012; Lightfoot et al. 2011; Miracle, Forenbaher 2005; 2006). However, the precise timing of these transformative events remains poorly defined, in part due to an ephemeral and uneven Mesolithic record in the Adriatic region (Biagi 2003; Komšo 2006; Lelli et al. 2012; Miracle, Forenbaher 2005; Moore et al. 2007a; 2007b). In most regions, there is also an observable gap between Mesolithic and Neolithic occupational layers that prevents more definitive conclusions about the spread of farming technology and domesticates in the Early Neolithic (Bonsall et al. 2013; Biagi et al. 2008; Forenbaher, Miracle 2006; Malone 2003; McClure 2013; Mlekuž et al. 2008; Rowley-Conwy et al. 2013).

Consequently, the advent of farming in the region has been variously explained with diffusionist, migratory, or native developmental models (e.g., Bass 2008; Chapman et al. 1996; Forenbaher, Miracle 2005; Marijanović 2009; Mlekuž 2003; Moore et al. $2007 a ; 2007 b$ ). While developed Neolithic lifeways at key sites, such as Pokrovnik in Dalmatia, point to a rapid spread of a complete farming package (Legge, Moore 2011; McClure et al. 2014; McClure, Podrug 2015; Moore et al. 2007a; 2007b), evidence at other sites along the Mediterranean and Adriatic coasts suggests a much more gradual spread (Miracle, Forenbaher 2005). The role of local hunter-gatherer groups in bringing agriculture to the region has also been inconsistently defined, with some arguing for acculturation or adoption (Bonsall et al. 2013; Zvelebil, Lillie 2000) versus displacement by migratory farmers (Rowley-Conwy et al. 2013).

Despite these ambiguities, however, current archaeological survey and excavation along the Adriatic coast is clarifying the temporal and spatial trajectories of the spread of domesticated plants and animals and associated farming technology in the area (Dalmatia: Marijanović 2009; McClure et al. 2014; McClure, Podrug 2015; Miracle, Forenbaher 2006; Moore et al. 2007a; 2007b; Teoh et al. 2014; Istria: Forenbaher, Kaiser 2008; Forenbaher et al. 2013; Italy: Biagi 2003; Biagi et al. 2008; Malone 2003; Slovenia: Bonsall et al. 2007; Tomaž 2010). Though there are regional differences in the appearance of the standard Neolithic package, which included domestic wheat, barley, sheep, goats, pigs, and cattle, the Neolithic can generally be divided into Early, Middle, and Late sub-periods, and are often associated with regionally different but characteristic pottery styles. 
Impresso ware had arrived in Dalmatia with the first farming groups by the early $6^{\text {th }}$ millennium calBC (for new radiocarbon dates of Dalmatian Neolithic, see Forenbaher, Kaiser 2008; Forenbaher et al. 2013; Marijanović 2009; McClure et al. 2014; Miracle, Forenbaher 2006; Moore et al. 2007a; 2007b; Podrug 2010), and reached southern Istria by 5750 calBC (Forenbaher, Miracle 2006). The Middle Neolithic period in Dalmatia and southern Istria is marked by the appearance of Danilo pottery (c. 53004900 calBC), and the Late Neolithic by the use of Hvar style ware that lasts throughout most of the $5^{\text {th }}$ millennium and into the $4^{\text {th }}$ millennium BC ( $\mathrm{FO}^{-}$ renbaher et al. 2013; Forenbaher 2014). The first signs of the Neolithic in northern Istria and the Trieste Karst, however, do not appear until the second half of the $6^{\text {th }}$ millennium $B C$ with the appearance of Danilo-Vlaška pottery style (Miracle 2006; Forenbaher, Miracle 2006; Forenbaher 2014). In northeastern Italy, a local iteration of the Danilo and Hvar culture elements, as well as those from the Po valley is reported (Ferrari et al. 2014). In central and southeastern Italy, regional Early Neolithic impressed wares had appeared along the coast by the $6^{\text {th }}$ millennium BC (Malone 2003).

\section{Neolithic animal management in the Adriatic}

Despite more recent stable isotope studies (Lelli et al. 2012; Lightfoot et al. 2011; Ogrinc, Budja 2005; Zavodny et al. 2014) and ceramic residue analyses (Budja et al. 2013; Evershed et al. 2008; Šoberl et al. 2008), zooarchaeology remains the primary method for identifying Neolithic economies and animal exploitation strategies in the Adriatic since domesticated species dominate most faunal assemblages at both village and cave sites (Legge, Moore 2011; McClure 2013; Miracle, Forenbaher 2005; Miracle, Pugsley 2006; Moore et al. 2007a; 2007b; Radović et al. 2008; Rowley-Conwy et al. 2013). Population profiles and mortality curves act as proxies for herd management, and are used to estimate birthing and culling seasons for different species. Additionally, age-at-death profiles built from tooth eruption and wear patterns can be used to compare observed slaughter patterns with idealised curves for milk, wool, and meat exploitation (Payne 1973). According to Payne, when a species is managed primarily for milk production, very young individuals are slaughtered at a higher rate than adults. This contrasts with a strategy concentrated on meat production, where larger numbers of animals survive to be older juveniles or adults (e.g., Legge, Moore 2011; Payne 1973; Vigne, Helmer 2007), or a wool-driven economy, where as many animals are allowed to reach adulthood as possible.

Recent work at the cave sites of Pupicina (Miracle, Forenbaher 2006; Miracle, Pugsley 2006) and Vela Spila (Radović et al. 2008) in Istria have used mortality profiles to identify changes in herd composition and exploitation from the Middle Neolithic onwards. Radović and colleagues (2008) argue that ovicaprid remains at Vela Spila most closely resemble Payne's milk-curve, with juveniles likely being culled between early spring and late fall. Mortality curves of faunal remains at nearby Pupićina, however, have been interpreted as indicative of both meat and milk exploitation according to the season of site use (Miracle, Pugsley 2006; Rowley-Conwy et al. 2013). In Dalmatia, sheep age data from Pokrovnik suggest that early farmers practiced a mixed or meat-focused strategy (Legge, Moore 2011.187188), while in Italy, Rowley-Conwy et al. (2013) argue that southern Italian farmers exploited ovicaprids for milk and cows for meat.

However, kill-off models provide only an approximation of animal management, and other factors such as accidental mortality, disease (e.g., Legge, Moore 2011.187), mixed management strategies, and statistical similarities between some practices may complicate interpretations of the archaeological record (e.g., Bréhard et al. 2010; Brochier 2013; Greenfield 2005; Vigne, Helmer 2007). Stable isotope and lipid residue analyses can provide complimentary evidence of animal exploitation practices. For instance, analyses of lipid residues at sites in the Near East and southeastern Europe suggest that the processing of dairy products was present in some regions before the $7^{\text {th }}$ millennium BC (Evershed et al. 2008). In the Adriatic, dairy lipids have been identified on the inside of ceramics from the Middle Neolithic site Mala Triglavca, indicating the use of milk products by Vlaška groups (Budja 2014; Budja et al. 2013; Šoberl et al. 2008).

\section{The question of transhumance}

Seasonal transhumance, or annual rounds of herds between different grazing grounds, is a historically well-documented pastoral adaptation in the Mediterranean and Adriatic (Moore et al. 2007b; Porčić 2008; Šašel 1980). In the case of central Dalmatia, the seasonal movement of livestock to temporary pastures played a fundamental role in local farming adaptations well into the $20^{\text {th }}$ century (Moore et al. $2007 b$ ). Recent ethnographic work at the modern 
village of Pokrovnik, in Dalmatia, demonstrates the existence of a transhumant management strategy as recently as the past century, with herders pasturing sheep in the nearby Dinaric Alps during the summer months and wintering in the coastal valley alongside the village (Moore et al. 2007b). In this system, animals are able to graze on fresh grass, while allowing the land surrounding each village to regenerate from winter pasturing. Elsewhere in southeastern Europe, sedentary pastoralists have been identified in Neolithic Romania (Greenfield, Jongsma 2008), but transhumance as a pastoral strategy is not documented until the Bronze Age in the region (Arnold, Greenfield 2006).

The role of transhumance in the Neolithic is less clear. The distribution of archaeological sites suggests that higher elevation and/or rockier terrain in the Adriatic region were primarily used by pastoralists during the Neolithic (e.g., Istria, Slovenia; see Miracle 2006; Mlekuž 2003, 2005; see also Dennell 1978; Halstead 2006). Known cave sites like Pupićina and Vela Spila may have acted as seasonal outposts for shepherds and their flocks (Rowley-Conwy et al. 2013), and there is some evidence that ovicaprids and cows were stabled in caves at different points in prehistory (Bonsall et al. 2013; Boschian, Montagnari Kokelj 2000; Mlekuž 2005; Mlekuž et al. 2008). The predominance of ovicaprids at these and other cave sites (Rowley-Conwy et al. 2013) also implies a transhumant strategy, as cows and pigs were less likely to make seasonal rounds.

In one regional study of the northern Balkans, Arnold and Greenfield (2006) tested the hypothesis that a transhumant economy would cull more juveniles during springtime in the highlands, and more adults would die during the winter while pasturing near lowland villages. Similarly, analyses of the Pupičina assemblage have identified the majority of ovicaprid remains as belonging to neonates and juveniles (6081\%; Miracle, Pugsley 2006). Assuming a single birthing season in the early spring, researchers suggest that Neolithic shepherds brought their flocks to the cave sites in the spring and summer to graze, before moving back into the lowlands during the colder months.

\section{Stable isotopes, diet, and animal management}

Stable carbon and nitrogen isotopes in bone collagen can be used as proxies of diet, and reflect the average dietary protein during the last several years of an animal's life (DeNiro, Epstein 1978; 1981). Animal diet is inferred based on the isotopic composi- tion of food at the trophic level of foods consumed. Anticipated differences in stable isotope values between species and over time can be attributed to changing patterns of mobility, residence, and, by extension, management strategies during the Neolithic as communities invested more time and energy in agricultural lifeways (see Fig. 2). Local environmental variation in basal productivity and water availability, as well as metabolic factors, can alter the stable isotope composition of bone and collagen (DeNiro, Epstein 1978; 1981; Towers et al. 2011).

We expect that animal management strategies and their corresponding isotopic signatures will remain similar throughout the circum-Adriatic during this time period, but that there will be clear differences between species due to different exploitation goals and practices. We hypothesise that ovicaprids participated in a seasonal pattern of transhumance between the coast and mountains, while cattle and pigs remained in coastal valleys near permanent settlements throughout the year (Markovic 1987; Nimac 1940; Perišic 1940). Carbon and nitrogen stable isotope values should reflect this difference if the practice was indeed implemented during the Neolithic in the Adriatic (see Fig. 2). We also suggest that if caves were used as seasonal sites for penning and culling practices, we should also see differences between values from cave and open-air settlement sites.

Finally, we expect wild local herbivores (deer and hare) to have isotopic signatures noticeably different from domestic animals, as their diet should reflect the local environment with limited anthropogenic influence. Deer (Capreolus capreolus and Cervus elaphus) isotope values are reported from $\mathrm{Pu}$ pićina, Karagadur, and Vela Spila Lošinj, while hare (Lepus sp.) isotope values are from Vela Spilja Lošinj and Ajdovska Jama. These samples represent the Early to Late Neolithic and most of the geographic region under consideration, but for this paper we present them as one group, with the assumption that all environments are similar (terrestrial $\mathrm{C}_{3}$ ) and do not change over time (Bailey 2000.139).

\section{Neolithic sites in the Adriatic region}

The similar ecological and environmental landscapes across the Adriatic region allow us to contextualise results from multiple studies reporting values for domesticated animals at Neolithic sites in Dalmatia (Croatia), Istria (Croatia), Italy, and Slovenia. The background of each site sampled in this study is given below. 


\section{Dalmatia}

Five Neolithic sites in central Dalmatia have archaeological evidence of intensive use of domestic animals and crops, suggesting that human populations were dependent on agriculture and livestock throughout the Neolithic. Isotope values are from Zavodny and colleagues' (2014) study on Neolithic transhumance in this coastal region.

Konjevrate is an Early Neolithic village located less than $10 \mathrm{~km}$ from Pokrovnik. The site is currently under a modern churchyard (Fig. 1). Test excavations from the 1990s remain unpublished (for a short description see Menđušić 1998), though recovered pottery, stone tools, and animal bones are curated by the Šibenik City Museum. The presence of Impresso style pottery places the site in the Early Neolithic and AMS radiocarbon dates attest to Early and Middle Neolithic occupations (McClure et al. 2014; McClure, Podrug 2015).

Pokrovnik, a village roughly three hectares in size, was occupied continuously throughout the Early and Middle Neolithic, and is located only a few kilometers from the Middle Neolithic site of Danilo Bitinj (Fig. 1 ; Moore et al. 2007b). Excavations were undertaken in 1979 (Brusić 2008), and more recently in 2006 (Moore et al. 2007b) and in 2010-2013 (unpublished). Reported radiocarbon dates suggest the site was occupied circa 6000-5100 calBC (Legge, Moore 2011; McClure et al. 2014), making it one of the earliest dated open-air Neolithic villages in Dalmatia. Recent studies have identified over $90 \%$ of the fau-

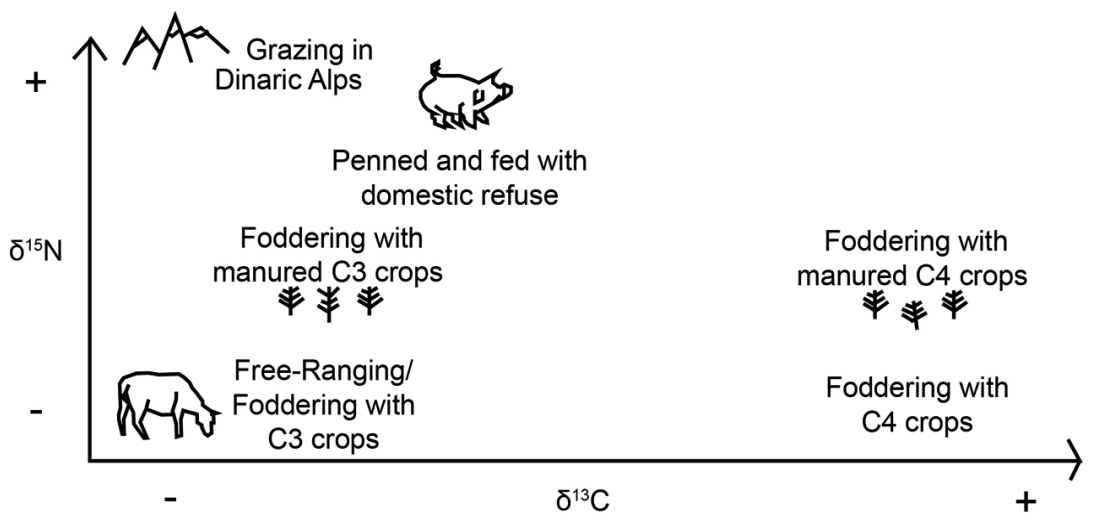

Fig. 2. Expected stable isotopic shifts according to different management strategies. Assuming free-ranging grazing or foddering with $C_{3}$ plants as a baseline, a switch to foddering with $C_{4}$ plants will enrich $813 \mathrm{C}$ by roughy 10-15\% (DeNiro, Epstein 1978). Foddering with manured crops, either $C_{3}$ or $C_{4}$, will enrich $\delta^{15 N}$ by 1-3\% (Bogaard et al. 2013). Animals fed with domestic refuse will shift to a higher trophic level, enriching $\delta^{13} \mathrm{C}$ by 1-3\%o and ${ }^{15} \mathrm{~N}$ by 3-5\% (Schoeninger, DeNiro 1984). Grazing exclusively at higher arid elevations, such as in the Dinaric Alps, will enrich $815 \mathrm{~N}$ in relation to lowland grazing individuals (Ambrose 1991). nal assemblage $(\mathrm{n}=2400)$ as domesticated species (Legge, Moore 2011; Moore et al. 2007b).

The Middle Neolithic settlement of Danilo Bitinj is located in a valley several kilometres from the Adriatic coast, and is thought to have been one of the most extensive sites of its type in southern Europe (Fig. 1; Moore et al. 2007a). Past excavations in 1953, 1955 (Korošec 1958; 1964), and 1992 (Menđušić 1998) provided a wealth of material, although more recent excavations have focused especially on the recovery and identification of over 1600 animal bones, most belonging to domesticates (Legge, Moore 2011; Moore et al. 2007a).

Krivače is another Middle Neolithic village located in the Bribir Valley (Fig. 1) and was first excavated in 1963 (Korošec, Korošec 1974), again during the early 2000s (unpublished), and most recently in 2013 (Podrug et al. 2013; see also McClure et al.

Čista Mala-Velištak is currently the only excavated Late Neolithic village in the region (Fig. 1; Podrug 2010). The available radiocarbon dates (4900-4700 calBC) place occupation at this site firmly in the early phase of the Hvar culture (McClure et al. 2014; McClure, Podrug 2015; Podrug 2010).

\section{Istria}

Carbon and nitrogen values are reported for domesticates from Neolithic sites located north of central Dalmatia in the coastal region of Istria (Fig. 1; Lightfoot et al. 2011). Lightfoot $e t$ al. (2011) focused on human dietary changes during the Mesolithic-Neolithic transition, finding a higher degree of dietary overlap between these periods than originally thought. Three sites have comparable isotopic data for domesticated animals: Kargadur, Vela Spilja-Lošinj, and Pupićina.

Kargadur is a coastal open-air village site that is one of the most recently excavated of its kind in Istria (Komšo 2006b). Vela Spilja-Lošinj is a prehistoric cave site, located on the island of Lošinj off the coast of Istria. Excavations during 
the 1950s uncovered a Mesolithic occupation (Mirosavljevic 1962; 1968; 1974), and more recent studies have also focused on Neolithic components of the site, including the identification of Early Impresso wares (Komšo et al. 2004).

Pupićina Cave, in inland Istria, was occupied numerous times throughout prehistory, and excavations have uncovered a significant Neolithic presence (Miracle, Forenbaher 2006). Zooarchaeological analysis of Neolithic animal remains have determined that domesticates comprised over $80 \%$ of identified taxa throughout the Neolithic (Miracle, Pugsley 2006). Ovicaprids comprise the majority of these domesticated faunal remains, although the presence of cattle and pigs increased in the Late Neolithic.

\section{Slovenia}

Located in southeastern Slovenia, Ajdovska Jama is an inland cave site that was infrequently occupied from the Paleolithic until the Middle Ages, though a series of archaeological excavations undertaken from 1884 onwards have uncovered a substantial Neolithic component (Bonsall et al. 2007; Horvat 1989). Early radiocarbon testing dated approximately 31 human burials to two periods within the Late Neolithic (Ogrinc, Budja 2005), although more recently published radiocarbon values for these same human remains cluster between 3485-3340 calBC (Bonsall et al. 2007.732). Domesticated sheep, goat, and cattle bones, many with clear cut marks, were found in burial contexts alongside hearths containing carbo-

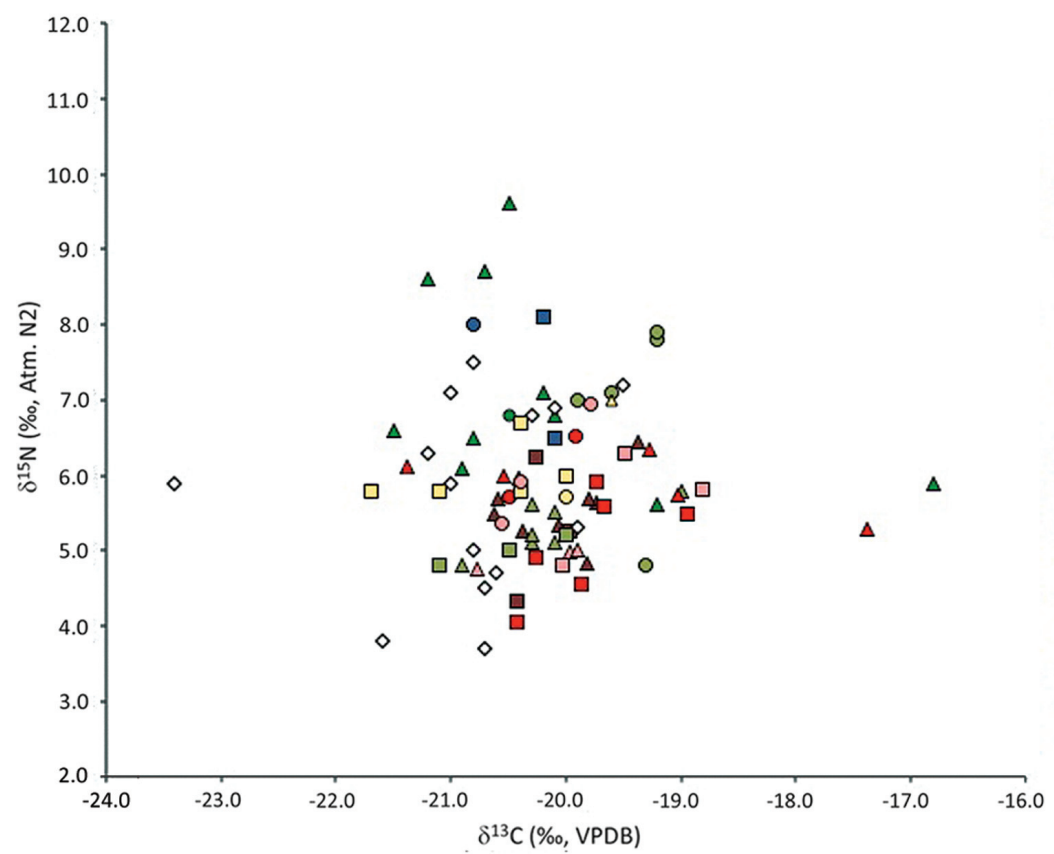

nised grain. A recent paleodietary study determined that Ajdovska Jama humans ate a 'terrestrial diet' of mostly domestic animals and $\mathrm{C}_{3}$ plants (Ogrinc, Budja 2005), a conclusion echoed by Clive Bonsall et al. (2007).

\section{Italy}

Recent research suggests that farming practices first spread along the eastern Adriatic coast and then crossed the sea to Italy by the start of the $6^{\text {th }}$ millennium BC (Lelli et al. 2012; Miracle, Forenbaher 2005; Skeates 2000; Starnini 2002). Similar to central Dalmatia, southeastern Italy also exhibits little evidence of a strong Mesolithic tradition (Biagi 2003; Lelli et al. 2012), making it an ideal point of comparison for mapping possible introductions and changes in animal husbandry among first farmers along the Adriatic coast.

Here we include stable carbon and nitrogen isotope values reported for domestic animals from four early Neolithic sites by Roberta Lelli et al. (2012; see Fig. 1) as part of a human paleodietary study. Radiocarbon dates indicate a Neolithic date for village sites: Ripa Tetta (5860-5600 calBC), Palata (5620-5470 calBC), and Balsignano (5570-5480 calBC). All of these sites are open-air settlements that were surrounded by ditch structures and whose inhabitants participated in an early agricultural economy. Palata and Balsignano are situated on the Adriatic coast, whereas Ripa Tetta is located farther inland. The fourth site, Grotta delle Mura, is a coastal cave dated

Fig. 3. Stable carbon and nitrogen values for all Neolithic samples discussed in this paper (Lelli et al. 2012; Lightfoot et al. 2011; Ogrinc, Budja 2005; Zavodny et al. 2014). 
to the Early Neolithic on the basis of Impressed Ware pottery associated with domesticated fauna. Collectively, these assemblages offer an opportunity to detect possible management differences on each side of the Adriatic.

\section{Discussion}

Here we compare the stable carbon and nitrogen isotope values for cows, ovicaprids, and pigs across the Neolithic Adriatic, as well as reported isotope values for local indigenous herbivores (hare and deer) as a control for non-human influenced diet in the environment. Values are reported in Table 1 and Figure 3.

Despite our initial predictions of temporal and species-specific changes in stable isotope signatures throughout the Neolithic period, Figure 3 demonstrates that such differences are not actually present over time or by region. We see a tight cluster of points, suggesting that cattle, ovicaprids, and pigs had largely similar diets throughout the Neolithic period regardless of region (Slovenia, Istria, Italy or Dalmatia). Reported isotope values for contemporary wild deer and hare in Istria and Slovenia also appear to overlap with domesticated values, suggesting that there may not have been much difference between human-managed and wild diets during this period. However, a uniform diet space does not necessarily mean that animal management remained the same through time or was the same for all species. Very little is known about the degree of uniformity in vegetation in the region, though indigenous plants were overwhelmingly $\mathrm{C}_{3}$ and evidence from Neolithic sites indicates that early agricultural staples - wheat, primarily einkorn and emmer, barley, and legumes - were also all $\mathrm{C}_{3}$ pathway plants as well (Bailey 2000. 139). $\mathrm{C}_{4}$ plants, such as millet, were presumably not in wide use by Neolithic communities in this region (Hunt et al. 2008), despite their presence in very small quantities at some sites (Legge, Moore 2011; Moore et al. 2007b).

Given zooarchaeological evidence consistent with seasonal rounds of ovicaprids between upland caves and lowland settlements (Miracle, Pugsley 2006; Radović et al. 2008), we might also expect isotopic differences according to archaeological context. If ovicaprids were lambed on their way to higher pastures and then culled there (Arnold, Greenfield 2006; Miracle, Pugsley 2006), ovicaprids from cave assemblages should have higher nitrogen values because of the majority of life spent at higher elevations (Ambrose 1991) and/or continued nursing until death (Nehlich et al. 2009; Richards et al. 2001). As seen in Figure 4, however, ovicaprid stable carbon and nitrogen values are clustered regardless of archaeological context and through time. Two-tailed t-tests (assuming unequal variances, Ruxton 2006) show no significant differences in carbon or nitrogen values between caves and settlements when compared $(\mathrm{p}=0.436$ and $\mathrm{p}$ $=0.472$, respectively). When caves and settlements are grouped according to period, however, there is a significant difference in reported stable nitrogen values for the Middle Neolithic Pupicina cave and contemporary settlements of Danilo-Bitinj, Krivače, and Pokrovnik $(\mathrm{p}=0.042)$. However, when a more conservative non-parametric Mann-Whitney $\mathrm{U}$ test is applied because of the small sample size (Fagerland 2012), this significance disappears $\left(\mathrm{U}=8.5, \mathrm{n}_{1}=5\right.$, $\mathrm{n}_{2}=5, \mathrm{p}>0.05$, two-tailed). Given these findings, we cannot confidently conclude whether the seasonal movement of ovicaprids was a mainstay of Neolithic economies in the circum-Adriatic region.

In addition, comparison of ovicaprids with wild herbivores generally, and between Middle Neolithic ovicaprids and all wild herbivores specifically, show

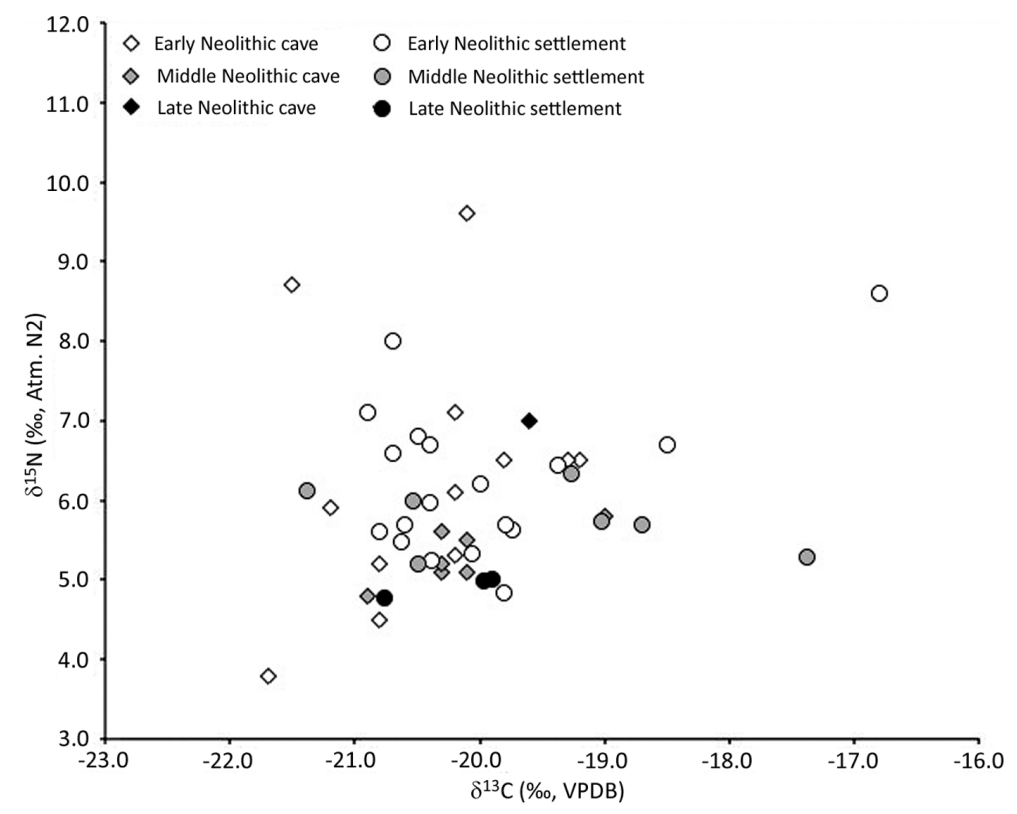

Fig. 4. Stable carbon and nitrogen isotope values of all Neolithic ovicaprids according to period and context (Lelli et al. 2012; Lightfoot et al. 2011; Ogrinc, Budja 2005; Zavodny et al. 2014). 
statistically significant differences in carbon values (t-test, unequal variances, $p=0.012$ and 0.014 , respectively), but not nitrogen. A MannWhitney U test comparing all wild herbivores, Middle Neolithic cave ovicaprids, and Middle Neolithic settlement ovicaprids similarly shows a significant difference in carbon ( $p$ $=0.045)$ but not nitrogen values ( $\mathrm{p}$ $=0.320$ ). We suggest the differences in carbon isotope values may be a result of different feeding strategies between species (e.g., browsing versus grazing or forest versus pasture; Bocherens et al. 2015; Lohse et al. 2014), although it is unclear whether these differences have anything to do with human intervention in animal diets.

One explanation for a similar diet space between cave and village animals is foddering. In this case, farmers provide animals with much of their subsistence, creating a very different kind of animal management system that may well have a similar isotopic signature regardless of the position of the herd in the seasonal round. Furthermore, the extent to which coastal valleys may have been preferred transhumance routes as opposed to transhumance to inland areas during the Neolithic is unknown, as current theories rely heavily on historical models in the region.

In short, current stable isotope data fall short in assessing the degree of transhumance during this period for ovicaprids.

A closer look at isotope values reported for pigs, however, reveals some differences in the species across time and space. Pigs are present in all regions during all periods (Figs. 3 and 5), and there appears to be a signal of changing management strategies between the Early and Middle-Late Neolithic. Statistical analyses highlight a significant difference in stable carbon values between Early and Middle Neolithic pigs (t-test assuming unequal variances, Ruxton 2006; $\mathrm{p}=0.0002)$ and Early and Late Neolithic pigs $(\mathrm{p}=0.003)$, although carbon and nitrogen values are not significantly different between Middle and Late Neolithic pigs $(\mathrm{p}=0.122$ and $\mathrm{p}=0.068$, respectively). We suggest that these differences in stable carbon and nitrogen signatures may reflect a shift in the foddering or management strategy of pigs be- tween Early and Middle-Late Neolithic times throughout the Adriatic.

Elevated nitrogen in pigs may reflect increased manuring practices in fields (Bogaard et al. 2013; Madgwick et al. 2012), penning (Bogaard et al. 2013), or different climatic and environmental settings (Madgwick et al. 2012). Statistically different carbon values for pigs between time periods may signal a change in foddering practices, such as the inclusion of small amounts of $\mathrm{C}_{4}$ species. Panicum miliaceum (broomcorn millet) is the most likely $\mathrm{C}_{4}$ candidate, having been recovered from archaeological contexts in Europe prior to 5000 calBC (Hunt et al. 2008), including Middle Neolithic contexts at Pokrovnik (Legge, Moore 2011; Moore et al. 2007b) and at sites in neighbouring Serbia (Gomolava, c. 3700-3600 calBC). However, just across the Adriatic, varieties of millet were not known in northern Italy until the early Bronze Age (c. 1700-1500 calBC; Tafuri et al. 2009; Zohary, Hopf 2000) or in southern Italy until Classical times (Tafuri et al. 2009). While it is possible that Middle and Late Neolithic sites in Dalmatia and Istria obtained and utilized domestic millet, either for feeding animals or as part of the human diet, the spread and adoption of this millet species in southeastern Europe remains unclear and the results presented here can neither support nor refute the clear presence of millet in the Adriatic Neolithic. 


\section{Conclusion}

Stable carbon and nitrogen isotope analyses provide a valuable tool for inferring changes in diet and environment. We find that the carbon and nitrogen isotope values reported in this paper remained largely stable for ovicaprids and cattle over the majority of the Neolithic, suggesting that livestock husbandry for these species remained fundamentally the same throughout the period in much of the Adriatic. Stable isotope data for domesticated pigs, on the other hand, may indicate different foddering or management practices as the Neolithic period progressed. Despite faunal data and other types of archaeological evidence, we also cannot definitively argue for or against ovicaprid transhumance on the basis of current stable isotope results. Future studies should focus on expanding sample sizes for domesticated animals at sites reported here and other Neolithic occupations throughout the circum-Adriatic region. Additionally, there is a need for background isotopic information on vegetation, either wild or domesticated, that may have been used for foddering or grazing by early farmers. Our results demonstrate the utility of isotope studies for addressing important questions regarding the Neolithic in the Adriatic, and highlight the need to continue quantitative scientific studies in the region.

\section{ACKNOWLEDGEMENTS}

Special thanks to Marko Menđušić, Andrew Moore, and Joško Zaninović for access to Dalmatian samples, and Karen and Jennifer Trippett for help with sample processing. Funding was provided by The Pennsylvania State University and the National Science Foundation (BCS-1460369, DJK and BJC).

Tab. 1. Summary of stable isotope results for samples included in this study, organised by region.

\begin{tabular}{|c|c|c|c|c|c|c|c|c|}
\hline Region & Site & Period & Sample \# & Species & $\Delta^{13 C}$ & $\Delta^{15 N}$ & $\mathrm{C}: \mathrm{N}$ & Reference \\
\hline \multirow{34}{*}{$\begin{array}{l}\text { Dalmatia, } \\
\text { Croatia }\end{array}$} & Konjevrate & Early & $\mathrm{KON}-2$ & Ovis aries & -19.8 & 4.8 & 3.24 & \multirow{17}{*}{ Zavodny et al. 2014} \\
\hline & & Early & $\mathrm{KON}-4$ & Ovis aries & -19.4 & 6.4 & 3.20 & \\
\hline & \multirow{15}{*}{ Pokrovnik } & Early & $\mathrm{KON}-5$ & Bos taurus & -20.3 & 6.2 & 3.26 & \\
\hline & & Early & PK-3 & Ovis aries & -20.6 & 5.7 & 3.19 & \\
\hline & & Early & PK-4 & Ovis aries & -19.8 & 5.7 & 3.16 & \\
\hline & & Early & PK-5 & Ovis aries & -20.4 & 6.0 & 3.18 & \\
\hline & & Early & PK-7 & Bos taurus & -20.4 & 4.3 & 3.16 & \\
\hline & & Early & PK-15 & Ovis aries & -20.1 & $5 \cdot 3$ & 3.17 & \\
\hline & & Early & PK-19 & Ovis aries & -19.7 & 5.6 & 3.17 & \\
\hline & & Early & PK-21 & Ovis aries & -20.4 & 5.2 & 3.18 & \\
\hline & & Early & PK-22 & Ovis aries & -20.6 & $5 \cdot 5$ & 3.17 & \\
\hline & & Early & PK-37 & Bos taurus & -20.0 & $5 \cdot 3$ & 3.17 & \\
\hline & & Middle & PK-14 & Bos taurus & -19.7 & 5.6 & 3.2 & \\
\hline & & Middle & PK-27 & Sus scrofa & -19.9 & 6.5 & 3.3 & \\
\hline & & Middle & PK-31 & Ovis aries & -20.5 & 6.0 & $3 \cdot 3$ & \\
\hline & & Middle & PK-36 & Bos taurus & -18.9 & $5 \cdot 5$ & 3.0 & \\
\hline & & Middle & PK-39 & Bos taurus & -19.7 & 5.9 & 3.2 & \\
\hline & \multirow[t]{2}{*}{ Danilo } & Middle & DA-6 & Ovis aries & -19.0 & 5.7 & 3.21 & \multirow[t]{2}{*}{ Zavodny et al. 2014} \\
\hline & & Middle & DA-13 & Ovis aries & -17.4 & $5 \cdot 3$ & 3.21 & \\
\hline & \multirow[t]{6}{*}{ Krivače } & Middle & KRI-1 & Ovicaprid & $-19 \cdot 3$ & 6.3 & 3.2 & \multirow[t]{6}{*}{ Zavodny et al. 2014} \\
\hline & & Middle & $\mathrm{KRI}-2$ & Sus scrofa & -20.5 & 5.7 & $3 \cdot 3$ & \\
\hline & & Middle & $\mathrm{KRI}-3$ & Bos taurus & -20.4 & 4.0 & 3.1 & \\
\hline & & Middle & KRI-9 & Ovis aries & -21.4 & 6.1 & 3.2 & \\
\hline & & Middle & KRI-10 & Bos taurus & -19.9 & 4.6 & 3.2 & \\
\hline & & Middle & KRI-11 & Bos taurus & -20.3 & 4.9 & 3.2 & \\
\hline & \multirow{9}{*}{ Čista Mala-Velištak } & Late & CMV-1 & Sus scrofa & -20.6 & 5.4 & 3.2 & \multirow[t]{9}{*}{ Zavodny et al. 2014} \\
\hline & & Late & CMV-2 & Bos taurus & -19.5 & 6.3 & 3.2 & \\
\hline & & Late & $C M V-3 A$ & Bos taurus & -18.8 & 5.8 & 3.1 & \\
\hline & & Late & $\mathrm{CMV}-4$ & Sus scrofa & -20.4 & 5.9 & 3.2 & \\
\hline & & Late & CMV-5 & Ovis aries & -20.8 & 4.8 & 3.2 & \\
\hline & & Late & CMV-6 & Sus scrofa & -19.8 & 7.0 & 3.2 & \\
\hline & & Late & CMV-7 & Bos taurus & -20.0 & 4.8 & 3.2 & \\
\hline & & Late & $C M V-28$ & Capra hircus & -20.0 & 5.0 & 3.2 & \\
\hline & & Late & CMV-38 & Capra hircus & -19.9 & 5.0 & 3.2 & \\
\hline \multirow{3}{*}{$\begin{array}{l}\text { Istria, } \\
\text { Croatia }\end{array}$} & Kargadur & Early & $\mathrm{BB} 13$ & Ovicaprid & -20.9 & 7.1 & 3.2 & \multirow[t]{3}{*}{ Lightfoot et al. 2011} \\
\hline & & Early & $\mathrm{BB} 14$ & Ovis aries & -16.8 & 8.6 & 3.1 & \\
\hline & & Early & BB 16 & Ovis aries & -20.8 & 5.6 & 3.2 & \\
\hline
\end{tabular}


Emily Zavodny, Sarah B. McClure, Brendan J. Culleton, Emil Podrug and Douglas J. Kennett

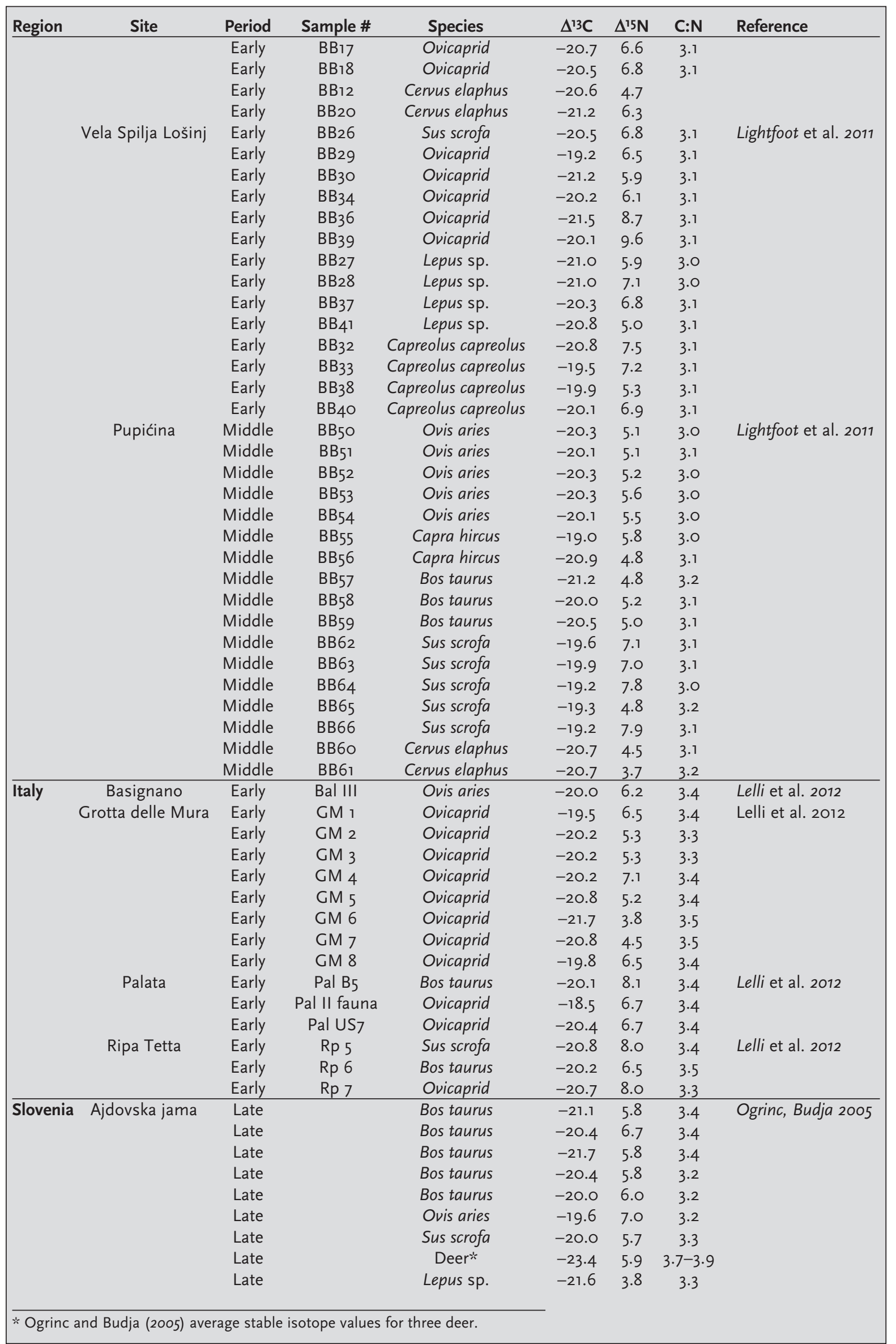




\section{References}

Ambrose S. 1991. Effects of diet, climate and physiology on nitrogen isotope abundances in terrestrial foodwebs. Journal of Archaeological Science 18: 293-317.

Arnold E., Greenfield H. 2006. The Origins of Transhumant Pastoralism in Temperate Southeastern Europe. Archaeopress. Oxford.

Bailey D. 2000. Balkan prehistory: exclusion, incorporation and identity. Routledge. London.

Balasse M., Cocherens H., Tresset A., Vigne J. and Mariotti A. 1997. Émergence de la production latière au Néolithique? Contribution de l'analyse isotopique d'ossements de bovins archéologiques. Compes rendus de l'Académie des Sciences de Paris. Sciences de la Terre et des Planétes 325: 105-110.

Bass B. 2008. Early Neolithic communities in southern Dalmatia: farming seafarers or seafaring farmers? European Journal of Archaeology 11: 245-265.

Biagi P. 2003. A review of the Late Mesolithic in Italy and its implications for the Neolithic Transition. In A. Ammerman, P. Biagi (eds.), The Widening Harvest. The Neolithic Transition in Europe: Looking Back, Looking Forward. Archaeological Institute of America. Boston: 133-155.

Biagi P., Starnini E. and Voytek B. 2008. The MesolithicNeolithic transition in the Trieste Karst (north-eastern Italy) as seen from the excavations at the Edera Cave. In C. Bonsall, V. Boroneant and I. Radovanović (eds.), The Iron Gates in prehistory: new perspectives. British Archaeological Reports IS 189. Archaeopress. Oxford: 32503260 .

Bocherens H., Hofman-Kamińska E., Drucker D. G., Schmölcke U. and Kowalcyzk R. 2015. European Bison as a Refugee Species? Evidence from Isotopic Data on Early Holocene Bison and Other Large Herbivores in Northern Europe. PLoS One 10: online http://doi.org/10.1371/jour nal. pone.0115090.

Bocherens H., Mashkour M. and Billiou D. 2000. Palaeoenvironmental and archaeological implications of isotopic analyses $(13 \mathrm{C}, 15 \mathrm{~N})$ from Neolithic to present in Qazvin Plain, Iran. Environmenal Archaeology 5: 1-19.

Bocherens H., Mashkour M., Billiou D. Pellé E. and Mariotti A. 2001. A new approach for studying prehistoric herd management in arid areas: intra-tooth isotopic analyses of archaeological caprine from Iran. Comptes Rendus de l'Académie des Sciences - Series IIA - Earth and Planetary Science 332: 67-74.
Bogaard A., Fraser R., Heaton T. H. E., Wallace M., Vaiglova P., Charles M., Jones G., Evershed R. P., Styring A. K., Andersen N. H., Arbogast R.-M., Bartosiewicz L., Gardeisen A., Kanstrup M., Maier U., Marinova E., Ninov L. Schäfer M. and Stephan E. 2013. Crop manuring and intensive land management by Europe's first farmers. Proceedings of the National Academy of Sciences 110: 12589-12594.

Bonsall C., Horvat M., McSweeney K., Masson M., Higham T., Pickard C. and Cook G. 2007. Chronological and dietary aspects of the human burials from Ajdovska Cave, Slovenia. Radiocarbon 49: 727-740.

Bonsall C., Mlekuž D., Bartosiewicz L. and Pickard C. 2013. Early farming adaptations of the northeast Adriatic karst. In S. Colledge, J. Conolly, K. Dobney, K. Manning, and S. Shennan (eds.), The origins and spread of domestic animals in southwest Asia and Europe. Left Coast Press. Walnut Creek, CA: 145-160.

Boschian G., Montagnari-Kokelj E. 2000. Prehistoric shepherds and caves in the Trieste Karst (northeastern Italy). Geoarchaeology 150: 331-371.

Bréhard S., Beeching A. and Vigne J.-D. 2010. Shepherds, cowherds and site function on middle Neolithic sites of the Rhône valley: an archaeozoological approach to the organization of territories and societies. Journal of Anthropological Archaeology 29: 179-188.

Brochier J. É. 2013. The use and abuse of culling profiles in recent zooarchaeological studies: some methodological comments on "frequency correction" and its consequences. Journal of Archaeological Science 40: 1416-1420.

Brusić Z. 2008. Pokrovnik - naselje iz neolitika. Muzeja grada Šibenika. Šibenik.

Budja M., Ogrinc N., Žibrat Gašparič A., Potočnik D., Žigon D. and Mlekuž D. 2013. Transition to farming- transition to milk culture: a case study from Mala Triglavca, Slovenia. Documenta Praehistorica 40: 97-117.

Budja M. 2014. Neolithic transition to farming in northern Adriatic. Lactose tolerance, dairying and lipid biomarkers on pottery. Archaeologia Adriatica 7(1): 53-75.

Chapman J., Shiel R. and Batović Š. 1996. The Changing Face of Dalmatia: Archaeological and Ecological Studies in a Mediterranean Landscape. Leicester University Press. London.

Dennell R. 1978. Early Farming in South Bulgaria from the VIth to the IInd Millennia BC. British Archaeological Reports IS 47. Archaeopress. Oxford. 
Evershed R. P. Payne S., Sherratt A. G., Copley M. S., Coolidge J., Urem-Kotsu D., Kotsakis K., Özdoğan M., Özdoğan A. E., Nieuwenhuyse 0., Akkermans P. M. M. G., Bailey D., Andeescu R.-R., Campbell S., Farid S., Hodder I., Yalman N., Özbaşaran M., Biçakci E., Garfinkel Y., Levy T. and Burton M. M. 2008. Earliest date for milk use in the Near East and southeastern Europe linked to cattle herding. Nature 455: 528-531.

Fagerland M. W. 2012. T-tests, non-parametric tests, and large studies - a paradox of statistical practice? BMC Medical Research Methodology 12: 78.

Ferrari A., Pessina A. and Visentini P. 2014. Friuli and the Trieste Karst in the Neolithic. In P. Visentini, E. Podrug (eds.), Adriatico senza confini. Civici Musei di UdineMuseo Friulano di Storia Naturale. Udine: 109-117.

Forenbaher S., Kaiser T. and Miracle P. T. 2013. Dating the East Adriatic Neolithic. European Journal of Archaeo$\log$ y 54: 589-609.

Forenbaher S. 2014. Eastern Adriatic Neolithic. In P. Visentini, E. Podrug (eds.), Adriatico senza confini. Civici Musei di UdineMuseo Friulano di Storia Naturale. Udine: 43-57.

Forenbaher S., Kaiser T. 2008. Grapčeva Špilja: pretpovijesni stan, tor i obredno mjesto. Rezultati arheološkog istraživanja 1996. godine. Biblioteka znanstvenih djela 159. Književni krug. Split.

Forenbaher S., Miracle, P. 2005. The spread of farming in the eastern Adriatic. Antiquity 79: 514-528.

2006. The spread of farming in the eastern Adriatic. Documenta Praehistorica 33: 89-100.

Greenfield H. 2005. A reconsideration of the Secondary Products Revolution in south-eastern Europe: on the origins and use of domestic animals for milk, wool, and traction in the central Balkans. In J. Mulville, A. K. Outram (eds.), The Zooarchaeology of Fats, Oils, Milk and Dairying. Oxbow. Oxford: 14-31.

Greenfield H., Jongsma T. 2008. Sedentary pastoral gatherers in the early Neolithic: architectural, botanical, and zoological evidence for mobile economies from FoeniSalass, south-west Romania. In D. Bailey, A. Whittle and D. Hofman (eds.), Living Well Together? Settlement and Materiality in the Neolithic of South-East and Central Europe. Oxbow Books. London: 108-130.

Halstead P. 2006. Sheep in the garden: the integration of crop and livestock husbandry in early farming regimes of Greece and southern Europe. In D. Serjeantson, D. Field (eds.), Animals in the Neolithic of Britain and Europe. Oxbow Books. Oxford: 42-55.
Horvat M. 1989. Ajdovska jama pri Nemški vasi. Znanstveni inštitut Filozofske fakultete. Ljubljana.

Hunt H., Vander Linden M., Liu X., Motuzaite-Matuzeviciute G., Colledge S. and Jones M. 2008. Millets across Eurasia: chronology and context of early records of the genera Panicum and Setaria from archaeological sites in the old World. Vegetation History and Archaeobotany 17: 5-18. Komšo D. 2006a. The Mesolithic in Croatia. Opuscula archaeologica 30: 55-92.

2006b. Kargadur - eine Seidlung aus dem frühen- und mittleren Neolithikum Istriens. Mitteilungen der Berliner Gesellschaft für Anthropologie, Ethnologie und Urgeschichte 27: 111-118.

Komšo D., Miracle P. T. and Boschian G. 2004. Istraživanje Vele spilje na Lošinju. Hrvatski Arheološki godišnjak 1: $172-175$.

Korošec J. 1958. Neolitska naseobina u Danilu Bitinju. Jugoslavenska akademija znanosti i umjetnosti. Zagreb.

1964. Danilo in Danilska kultura. Univerza v Ljubljani. Ljubljana.

Korošec J., Korošec P. 1974. Bribir i njegova okolica u prapovijesno doba. Diadora 7: 5-33.

Legge A., Moore A. T. 2011. Clutching at straw: the Early Neolithic of Croatia and the dispersal of agriculture. In A. Hadjikoumis, E. Robinson and S. Viner (eds.), The dynamics of Neolithisation in Europe: studies in honor of Andrew Sherratt. Oxbow Books. Oxford: 176-195.

Lelli R., Allen R., Biondi G., Calattini M., Barbaro C., Gorgoglione M., Manfredini A., Martinez-Labarga C., Radina F., Silvestrini M., Tozzi C., Rickards 0. and Craig 0. 2012. Examining dietary variability of the earliest farmers of south-eastern Italy. American Journal of Physical Anthropology 149: 380-390.

Lightfoot E., Boneva B., Miracle P. T., Slaus M. and O'Connell T. 2011. Exploring the Mesolithic and Neolithic transition in Croatia through isotopic investigations. Antiquity 85: 73-86.

Lohse J. C., Madsen D. B., Culleton B. J. and Kennett D. J. 2014. Isotope paleoecology of episodic mid-to-late Holocene bison population expansions in the Southern Plains, U.S.A. Quaternary Science Reviews 102: 14-26.

Madgwick R., Mulville J. and Stevens R. 2012. Diversity in foddering strategy and herd management in Late Bronze Age Britain: an isotopic investigation of pigs and other fauna from two midden sites. Environmental Archaeo$\log y$ 17: 126-140. 
Makarewicz C., Tuross N. 2006. Foddering by Mongolian pastoralists is recorded in the stable carbon $\left(\delta^{13} \mathrm{C}\right)$ and nitrogen $\left(\delta^{15} \mathrm{~N}\right)$ isotopes of caprine dentinal collagen. Journal of Archaeological Science 33: 862-870.

Malone C. 2003. The Italian Neolithic: a synthesis of research. Journal of World Prehistory 17: 235-312.

Marijanović B. 2009. Crno Vrilo 1. Sveučilište u Zadru. Zadar.

Marković M. 1987. Stočarstvo na Dinari. Stočarstvo 41 : 257-273.

McClure S. B. 2013. Domesticated animals and biodiversity: early agriculture at the gates of Europe and longterm ecological consequences. Anthropocene. on-line http://dx.doi.org/10.1016/j.ancene.2013.11.001

McClure S. B., Podrug E. 2015. Villages, landscapes and early farming in northern Dalmatia. In M. Chazan, K. T. Lillios (eds.), Fresh Fields and Pastures New: Papers Presented in Honor of Andrew M. T. Moore. Sidestone Press. Leiden: in press.

McClure S. B., Podrug E., Moore A. M. T., Culleton B. J. and Kennett D. J. 2014. AMS ${ }^{14} \mathrm{C}$ Chronology and Ceramic Sequences of Early Farmers in the Eastern Adriatic. Radiocarbon 56: 1019-1038.

Menđušić M. 1998. Neolitička naselja na Šibensko-drniškom području. Izdanja Hrvatskog arheološkog društva 19: 47-62.

Miracle P. 2006. Neolithic shepherds and their herds in the Northern Adriatic Basin. In D. Serjeantson, D. Field (eds.), Animals in the Neolithic of Britain and Europe. Oxbow Books. Oxford: 63-94.

Miracle P., Forenbaher S. 2005. Neolithic and Bronze-Age herders of Pupicina Cave, Croatia. Journal of Field Archaeology 30: 255-281.

2006. Pupicina Cave and the spread of farming in the Eastern Adriatic. In P. Miracle, S. Forenbaher (eds.), Prehistoric herders of northern Istria: the archaeology of Pupicina Cave, vol 1. Arheološki Muzej Istre. Pula: 483-530.

Miracle P., Pugsley L. 2006. Vertebrate faunal remains from Pupićina Cave. In P. Miracle, S. Forenbaher (eds.), Prehistoric herders of northern Istria: the archaeology of Pupicina Cave, vol 1. Arheološki Muzej Istre. Pula: 259-400.

Mirosavljević V. 1962. Impresso-cardium keramika na otocima Cresa, Lošinja i Krka. Prilog prethistoriji jadranskog kulturnog kruga. Arheološki radovi i rasprave 2: 175-209.
1968. Vela Spilja prethistorijsko nalzište na otoku Lošinju. Arheološki radovi $i$ rasprave 6: 27-60.

1974. Gradine i gradinski sistemi u prethistorijsko i protohistorijsko doba. Arheološki radovi $i$ rasprave 7: 259-297.

Mlekuž D. 2003. Early herders of the Eastern Adriatic. Documenta Praehistorica 30: 139-151.

2005. The ethnography of the Cyclops: Neolithic pastoralists in the eastern Adriatic. Documenta Praehistorica 32: 15-51.

Moore A. T., Menđušić M., Smith J., Zaninović J. and Podrug E. 2007a. Project "Early farming in Dalmatia": Danilo Bitinj 2004-2005. Vjesnik Arheološkog muzeja u Zagrebu 40: 15-24.

Moore A. T., Menđušić M., Smith J., Podrug E. and Zaninović J. 2007b. Project "Early farming in Dalmatia": Pokrovnik 2006. Vjesnik Arheološkog muzeja u Zagrebu 40: 25-34.

Nehlich 0., Montgomery J., Evans J., Schade-Lindig S., Pichler S., Richards M. and Alt K. 2009. Mobility or migration: a case study from the Neolithic settlement of Nierder-Mörien (Hessen, Germany). Journal of Archaeological Science 36: 1791-1799.

Nimac N. 1940. Čobanovanje. Život i tradicije pastira Dalmatinske zagore na bosanskim planinama. Etnografska istraživanja I grada II: 102-130.

Ogrinc N., Budja M. 2005. Paleodietary reconstruction of a Neolithic population in Slovenia: a stable isotope approach. Chemical Geology 218: 103-116.

Payne S. 1973. Kill-off patterns in sheep and goats: the mandibles from Asvan Kale. Anatolian Studies 23: 281303.

Pearson J., Buitenhuis H., Hedges R. E. M., Martin L., Russell N. and Twiss K. 2007. New light on early caprine herding strategies from isotope analysis: a case study from Neolithic Anatolia. Journal of Archaeological Science 34: 2170-2179.

Perišić I. 1940. Prilozi o čobanovanju na Šator-planini. Etnografska istraživanja i grada II: 131-142.

Podrug E. 2010. Čista Mala-Velištak: prve tri istraživačke kampanje na nalazištu hvarske culture/ Čista Mala-Velištak: the first three excavation campaigns at a Hvar culture site. Diadora 24: 7-25.

Podrug E., McClure S. B. and Solter A. 2013. Lokalitet: Bribir - Krivače. Hrvatski arheološki godišnjak 10 in press. 
Porčić M. 2008. Nomadic pastoralism in the Early Bronze Age of the Central Balkans - evaluation of background knowledge. Balcanica 39: 7-31.

Radović S., Forenbaher S., Brajković D., Mauch Lenardić J., Malez V. and Miracle P. T. 2008. Use of caves in the mountains: a view from the sheepfold. In T. Kalicki, B. Szmoniewski (eds.), Man and Mountains: paleogeographical and archaeological perspectives. Studies of the Institute of Geography UJK. Kielce: 33-50.

Richards M., Mays S. and Fuller B. 2002. Stable carbon and nitrogen isotope values of bone and teeth reflect weaning age at the Medieval Wharram Percy site, Yorkshire, UK. American Journal of Physical Anthropology 119: 205210.

Rowley-Conwy P., Gourichon L., Helmer D. and Vigne J.D. 2013. Early domestic animals in Italy, Istria, the Tyrrhenian Islands and Southern France. In S. Colledge, J. Conolly, K. Dobney, K. Manning and S. Shennan (eds.), Domestic Animals in Southwest Asia and Europe. Left Coast Press. Walnut Creek, CA: 161-194.

Ruxton G. 2006. The unequal variance t-test is an underused alternative to Student's t-test and the Mann-Whitney U test. Behavioral Ecology 17: 688-690.

Šašel J. 1980. Pastorizia e transhumanza. Contributo alla discussione. Rivista Storica dell'Antichita 10: 179-185.

Schoeninger M., DeNiro M. 1984. Nitrogen and carbon isotopic composition of bone collagen from marine and terrestrial animals. Geochimica et Cosmochimica Acta 48: 625-639.

Skeates R. 2000. The social dynamics of enclosure in the Neolithic of the Tavoliere, south-east Italy. Journal of Mediterranean Archaeology 13: 155-188.

Šoberl L., Žibrat Gašparič A., Budja M. and Evershed R. P. 2008. Early herding practices revealed through organic residue analysis of pottery from the early Neolithic rock shelter of Mala Triglavca, Slovenia. Documenta Praehistorica 35: 253-260.
Starnini E. 2002. La ceramic impressa della'Adriatico orientale e dei Balcani. In M. Fugazzola Delpino, A. Pessina, and V. Tiné (eds.), La ceramiche impresse nel Neolitico antico. Italia e Mediterraneo. Istituto Poligrafico e Zecca dello Stato. Rome: 29-35.

Tafuri M. A., Craig 0. and Canci A. 2009. Stable isotope evidence for the consumption of millet and other plants in Bronze Age Italy. American Journal of Physical Anthropology 139: 146-153.

Teoh M. L., McClure S. B. and Podrug E. 2014. Macroscopic, petrographic and XRD analysis of figulina pottery from central Dalmatia. Journal of Archaeological Science 50: 350-358.

Tomaž A. 2010. The Neolithic in continental Slovenia according to the radiocarbon chronology: where can it be placed? Gortania 32: 71-86.

Towers J., Jay M., Mainland I., Nehlich 0 . and Montgomery J. 2011. A calf for all seasons? The potential of stable isotope analysis to investigate prehistoric husbandry practices. Journal of Archaeological Science 38: 1858-1868.

Vigne J., Helmer D. 2007. Was milk a "secondary product" in the old World Neolithisation process? Its role in the domestication of cattle, sheep and goats. Anthropozoologica 42: 9-40.

Zohary D., Hopf M. 2000. Domestication of plants in the Old World (third edition). Oxford University Press. Oxford.

Zavodny E., McClure S. B., Culleton B. J., Kennett D. J. and Podrug E. 2014. Neolithic animal management practices and stable isotope studies in the Adriatic. Environmental Archaeology 19: 184-195.

Zvelebil M., Lillie, M. 2000. Transition to agriculture in eastern Europe. In T. D. Price (ed.), Europe's first farmers. University Press. Cambridge: 57-92. 